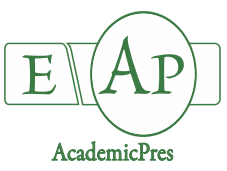

Andrade CG et al. (2021)

Notulae Botanicae Horti Agrobotanici Cluj-Napoca

Volume 49, Issue 1, Article number 12222

DOI: $10.15835 /$ nbha49112222

Research Article

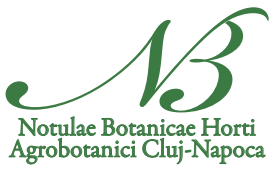

\title{
Viral diagnosis in cultivars of Ipomoea batatas (L.) Lam.
}

\section{Carlos G. ANDRADE ${ }^{1}$, Emanuel M. da SILVA², Carla RAGONEZI ${ }^{2,3 *}$, Miguel Â. A. PINHEIRO DE CARVALHO ${ }^{2,3,4}$}

\author{
${ }^{1}$ Universidad Central de Venezuela, Facultad de Farmacia, Cátedra de Farmacología, Piso 7, Oficina 715, Caracas, \\ Venezuela; carlosagda@hotmail.com \\ ${ }^{2}$ University of Madeira, ISOPlexis Center for Sustainable Agriculture and Food Technology, Campus da Penteada. 9020-105 \\ Funchal, Portugal; emasil2008@gmail.com; carla.ragonezi@staff.uma.pt('corresponding author); miguel.carvalho@staff.uma.pt \\ ${ }^{3}$ Centre for the Research and Technology of Agro-Environmental and Biological Sciences (CITAB), University of Trás-os-Montes \\ and Alto Douro, 5000-801 Vila Real, Portugal \\ ${ }^{4}$ University of Madeira, Faculty of Life Sciences, Campus da Penteada, 9020-105 Funchal, Portugal
}

\begin{abstract}
Ipomoea batatas (L.) Lam. commonly known as sweet potato, is an important staple food worldwide, mainly due to its high nutritional value and yield. However, vegetative reproduction of sweet potato makes it more susceptible to viral infections, which threatens its productivity, quality, and difficult long-term preservation in germplasm banks. Also, it can act as a virus reservoir infecting the rest of the plant accessions in the bank collections. Hence, this work aimed to screen Begomovirus, Potyvirus, and Carlavirus infections in 16 traditional sweet potato cultivars from the germplasm collection of the ISOPlexis Germplasm Bank, Madeira, Portugal. The infection prevalence by these viruses among cultivars was $81.25 \%, 25.00 \%$, and $6.25 \%$, respectively; being ISOP1011 the only accession coinfected by Potyvirus and Carlavirus. The accessions ISOP1006, ISOP1010, and ISOP1047 were also coinfected by Begomovirus and Potyvirus, highlighting their vulnerability to viral infections. The ISOP1005 and ISOP1027 accessions were the only ones not infected by any of these viruses. The analysis of the partial sequence obtained from the Carlavirus detected in the accession ISOP1011, revealed the existence of an ORF that encodes for 93 amino acids of the catalytic domain of an RNA-directed RNA polymerase related to the Tymovirus protein family, as could be confirmed by comparison with proteins stored in UniProtKB. Multiple sequence alignment with these proteins showed that Motifs A and B of the catalytic domain were conserved. The search for sequence similarity with sequences deposited in GenBank reported a high sequence identity with $S_{\text {weet }}$ potato yellow mottle virus (SPYMV) and $S_{\text {weet }}$ potato chlorotic fleck virus (SPCFV). However, the 9-11\% discrepancy in nucleotide sequence identity and a phylogenetic analysis carried out using the maximum probability method suggests the virus isolated from ISOP1011 is a new divergent strain of the SPCFV species.
\end{abstract}

Keywords: Carlavirus; cultivars; sweet potato; germplasm bank; molecular diagnosis; RdRp; phylogeny

Received: 14 Jan 2021. Received in revised form: 16 Mar 2021. Accepted: 17 Mar 2021. Published online: 24 Mar 2021.

From Volume 49, Issue 1, 2021, Notulae Botanicae Horti Agrobotanici Cluj-Napoca journal will use article numbers in place of the traditional method of continuous pagination through the volume. The journal will continue to appear quarterly, as before, with four annual numbers. 


\section{Introduction}

Sweet potato, Ipomoea batatas (L.) Lam. (Convolvulaceae), is the sixth most important food crop globally (International Potato Center, 2018), and it is cultivated in over 100 developing countries (FAOSTAT, 2012). Besides being an extremely versatile and delicious vegetable, it has high nutritional value and antioxidant, anti-cancer, antidiabetic, and anti-inflammatory activities. Therefore, it is considered a valuable source of unique natural products, e.g. development of medicines against several diseases and industrial products (Mohanraj and Sivasankar, 2014). Since this plant is highly susceptible to virus infections, diseases caused by these pathogens arise wherever sweet potato is cultivated (Lozano et al., 2009). Due to the predominant use of vegetative propagation, the accumulation and perpetuation of viruses can dramatically reduce crop production and even compromise its maintenance in plant collections such as genebanks.

The application of high-throughput sequencing (HTS) technologies to the screening of plant viruses, has allowed the detection of a great diversity of new viruses in many environments such as wild and domestic plants, and the interfaces between them, like aquatic systems, insects, and animal feces, demonstrating our limited knowledge about these viruses (Roossinck et al., 2015). Moreover, even the total diversity of DNA and RNA viruses found in whiteflies collected from a single site can be higher than the virus diversity described so far (Rosario et al., 2014).

Most plant viruses known have a single-stranded RNA genome and are classified into a continuously increasing number of genera (Desbiez et al., 2011; Umer et al., 2019). The RNA-directed RNA polymerase $(\mathrm{RdRp})$ is an enzyme essential for the replication of all viruses that lack a DNA stage in their life cycle. The positive-strand RNA viruses can undergo rapid mutational change, except in arrays of conserved sequence motifs of enzymes mediating the replication and expression of virus genomes, such as the RdRp (Koonin and Dolja, 1993). The RdRps are the most conserved of all proteins encoded by these viruses (Sabanadzovic et al., 2009).

Over 30 viruses infecting sweet potato, assigned to 9 families and over 20 viral genera have been reported to infect sweet potato (Clark et al., 2012; Cuellar et al., 2015). Among them Begomovirus, Potyvirus, and Carlavirus. The number continues to increase as virus detection methods are improved. The phenomena of recombination and reassortment of viral genomes can collaborate in the creation of new, emerging viruses, especially in chronic persistent infections where multiple viral genotypes co-replicate in a single host, generating abundant genotypic variants that can acquire novel host-colonizing and pathogenicity traits (Weng et al., 2007).

Viruses can be transmitted vertically or horizontally. Vertical transmission can occur through the infection of the seed, although it is not very common because most viruses fail to invade the embryo (Johansen et al., 1994). However, the efficient vertical transmission could happen if the plant has enough viable progeny to ensure virus maintenance or by seed envelopes contamination and infection of the seedling through the envelopes during germination. Vegetative propagation commonly found in plants, particularly in cultivated species, is very favourable for viruses due to the high frequency of transmission to the offspring (almost 100\%). Besides, the virus is already adapted to the progeny plants since they present the same genetic characteristics as the parent (Rice, 1983). This increases the infection frequency of viruses in asexual host populations of plants in comparison to populations with sexual reproduction (Ooi and Yahara, 1999). Additionally, viruses with horizontal transmission may evolve to more aggressive forms than vertical transmitted ones (Stewart et al., 2005; Elena et al., 2008).

Among the nine viruses of economic importance that reduce the productivity of sweet potato, three of them belong to the genus Potyvirus ( $S_{w e e t}$ potato feathery mottle virus, Sweet potato virus $G$, and $S_{w e e t}$ potato

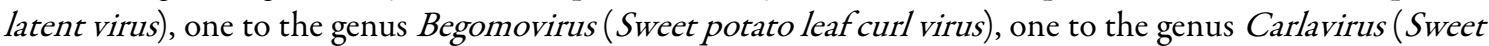
potato chlorotic fleck virus), and only the remaining four belong to other genera (Barkessa, 2018). Multiple infections with various viruses are common in the field, with the most frequent co-infection being caused by the aphid-borne $S_{\text {weet }}$ potato feathery mottle virus and the whitefly-transmitted $S_{\text {weet }}$ potato chlorotic stunt 
virus. This coinfection is responsible for the most devastating disease in sweet potato worldwide (Barkessa, 2018).

Considering that sweet potato has great economic and social importance, as it is one of the main sources of food and potential drugs for many human populations, coupled with the need to preserve its crop diversity in response to the greater vulnerability to viral infections because of its vegetative reproduction, the main objective of this work was to determine the prevalence of Begomovirus, Potyvirus, and Carlavirus in 16 traditional cultivars stored in the ISOPlexis Germplasm Bank of Madeira Island, Portugal. The Germplasm Bank is a facility of ISOPlexis Center, University of Madeira, Portugal, partner of the FAO genebank network (since 2001), Germobanco, the Macaronesia Genebank for Agriculture (since 2003) and AEGIS, a European Genebank Integrated System (since 2018). ISOPlexis has several years of experience in prospection, survey, conservation, evaluation, and add-value to the genetic resources for food and agriculture priority to Madeiran Autonomous Region, Portugal.

\section{Materials and Methods}

\section{Plant material}

The prevalence of infections generated by Begomovirus, Potyvirus, and Carlavirus in Ipomoea batatas (sweet potato) was evaluated in a total of 16 traditional cultivars, which were tested in quadruplicate. The tested cultivars correspond to the following ISOPlexis Genebank accession codes: ISOP1005, ISOP1006, ISOP1009, ISOP1010, ISOP1011, ISOP1012, ISOP1013, ISOP1016, ISOP1020, ISOP1021, ISOP1027, ISOP1028, ISOP1036, ISOP1038, ISOP1047, and ISOP1064. The accessions were considered positive for the infection when at least one of the samples of the 4 replicates from each accession tested positive for virus presence.

\section{Extraction of total nucleic acids (TNA) from sweet potato}

Total nucleic acids (TNA) extraction from healthy or infected plant samples was performed according to the extraction procedure 2 from Foissac et al. (2005). Aliquots of $150 \mu \mathrm{l}$ of the TNA resuspended in nucleasefree water were stored at $-20^{\circ} \mathrm{C}$ until later use.

Polyvalent detection of Potyviruses by Reverse Transcription Polymerase Chain Reaction (RT-PCR) All samples were tested by RT-PCR for the presence of potyviruses using the degenerated and inosines containing primers Nib2F and Nib3R developed by Zheng et al. (2010) (Table 1). Virus nomenclature was according to the International Code of Virus Classification and Nomenclature. In a first step, cDNA synthesis required the incubation of $5 \mu \mathrm{l}$ of TNA extract with $7 \mu \mathrm{l}$ of mix 1 (Poly T18 $1 \mu \mathrm{M}$, poly N6 $2 \mu \mathrm{M}$, dNTP 0.5 $\mathrm{mM}$ ) for $5 \mathrm{~min}$ at $65^{\circ} \mathrm{C}$, then $5 \mathrm{~min}$ in ice. After the addition of $8 \mu \mathrm{l}$ of mix 2 (reaction buffer 1X, DTT 0.01 $\mathrm{mM}$, RNaseOUT RNasin $40 \mathrm{U}$, Superscript II $200 \mathrm{U}$ ), the samples were incubated for $10 \mathrm{~min}$ at $25^{\circ} \mathrm{C}, 50$ min at $42{ }^{\circ} \mathrm{C}, 10 \mathrm{~min}$ at $70{ }^{\circ} \mathrm{C}$ and finally with $0.3 \mu \mathrm{lNAseH}(1 \mathrm{U})$ for $20 \mathrm{~min}$ at $37^{\circ} \mathrm{C}$. PCR amplification was performed mixing $5 \mu \mathrm{l}$ of cDNA with $45 \mu \mathrm{l}$ of the PCR mix [Reaction buffer $1 \mathrm{X}\left(\mathrm{MgCl}_{2} 15 \mathrm{mM}\right)$, Triton X100 0.2\%, Primer Nib2F $0.5 \mu \mathrm{M}$, Primer Nib3R $0.5 \mu \mathrm{M}$, dNTPs $0.25 \mathrm{mM}$, Dynazyme II $1 \mathrm{U}$ ], with 40 cycles at $95^{\circ} \mathrm{C}$ during $45 \mathrm{~s}, 45^{\circ} \mathrm{C}$ during $45 \mathrm{~s}$ and $72{ }^{\circ} \mathrm{C}$ during $45 \mathrm{~s}$. The reactions were then held at $4{ }^{\circ} \mathrm{C}$. 
Table 1. Primers used for PCR detection of viruses belonging to the genera Carlavirus, Potyvirus, and Begomovirus

\begin{tabular}{|c|c|c|c|c|c|}
\hline Virus & Primer & Primer sequence $5^{\prime} \rightarrow 3^{\prime}$ & $\begin{array}{c}\text { Target } \\
\text { sequence }\end{array}$ & $\begin{array}{l}\text { Expected } \\
\text { amplicon } \\
\text { size (bp) }\end{array}$ & Reference \\
\hline \multirow{5}{*}{ Carlavirus } & MC1 & TITTYWYIAARWSICARHTITGYAC & \multirow{5}{*}{$\begin{array}{c}\text { RNA } \\
\text { dependent } \\
\text { RNA } \\
\text { polymerase } \\
\text { (RdRp) }\end{array}$} & \multirow{5}{*}{358} & \multirow{5}{*}{$\begin{array}{l}\text { Couture et al. } \\
\text { (unpublished) }\end{array}$} \\
\hline & MC2 & GCIAARSBIGYICARWSIATYGTITG & & & \\
\hline & RMC5 & TCICCIGARAAICGCATRATIGC & & & \\
\hline & RMC6 & GMRCACATRTCRTCICCIGCIAARCA & & & \\
\hline & RMC7 & AVIYKCCAICCRCARAAISTIGG & & & \\
\hline \multirow[b]{2}{*}{ Potyvirus } & Nib2F & GTITGYGTIGAYGAYTTYAAYAA & \multirow{2}{*}{$\begin{array}{c}\text { NIb (large } \\
\text { Nuclear } \\
\text { Inclusion } \\
\text { Protein) }\end{array}$} & \multirow[b]{2}{*}{350} & \multirow[b]{2}{*}{$\begin{array}{l}\text { Zheng et al. } \\
\quad(2010)\end{array}$} \\
\hline & Nib3R & TCIACIACIGTIGAIGGYTGNCC & & & \\
\hline \multirow{2}{*}{ Begomovirus } & SweepoF2 & TGCCCGAAGYTATGTYCCGGT & \multirow{2}{*}{ REP gene } & \multirow{2}{*}{670} & \multirow{2}{*}{$\begin{array}{c}\text { Lett } \\
\text { (unpublished) }\end{array}$} \\
\hline & SweepoR & CCTGCARCGCAGDGTCTGATAYA & & & \\
\hline
\end{tabular}

$\mathrm{I}=$ Inosine; $\mathrm{Y}=\mathrm{C}, \mathrm{T} ; \mathrm{K}=\mathrm{G}, \mathrm{T} ; \mathrm{R}=\mathrm{A}, \mathrm{G} ; \mathrm{W}=\mathrm{A}, \mathrm{T} ; \mathrm{S}=\mathrm{G}, \mathrm{C} ; \mathrm{M}=\mathrm{C}, \mathrm{A} ; \mathrm{H}=\mathrm{A}, \mathrm{T}$.

\section{Polyvalent detection of carlaviruses by nested RT-PCR}

Polyvalent detection of carlaviruses was carried out by nested RT-PCR using the degenerated primers developed by INRAE Bordeaux (Table 1). Briefly, after cDNA synthesis following the protocol described for potyviruses, multiplex PCR was carried out using a reaction mixture containing $4 \mu \mathrm{l}$ of cDNA and $36 \mu \mathrm{l}$ of mix 1 [Reaction buffer $1 \mathrm{X}\left(\mathrm{MgCl}_{2} 15 \mathrm{mM}\right)$, Primer MC1 $1 \mu \mathrm{M}$, Primer RMC6 $1 \mu \mathrm{M}$, Primer RMC7 $1 \mu \mathrm{M}, \mathrm{MgCl}_{2}$ $2.5 \mathrm{mM}$, dNTPs $0.2 \mathrm{mM}$, Dynazyme II $1 \mathrm{U}]$. The temperature profile consisted of a denaturation step at $95^{\circ} \mathrm{C}$ for 3 min, 40 cycles of $30 \mathrm{~s}$ at $95^{\circ} \mathrm{C}, 30 \mathrm{~s}$ at an annealing temperature of $42{ }^{\circ} \mathrm{C}$, and $30 \mathrm{~s}$ at $72{ }^{\circ} \mathrm{C}$. The PCR reaction was held at $15^{\circ} \mathrm{C}$ until the step of nested PCR amplification, which required mixing $1 \mu$ l of this PCR 1 with $39 \mu \mathrm{l}$ of a Nested-PCR mix [reaction buffer $1 \mathrm{X}\left(\mathrm{MgCl}_{2} 15 \mathrm{mM}\right)$, Primer MC2 $1 \mu \mathrm{M}$, Primer RMC5 1 $\mu \mathrm{M}, \mathrm{MgCl}_{2} 2.5 \mathrm{mM}$, dNTPs $0.2 \mathrm{mM}$, Dynazyme II $\left.1 \mathrm{U}\right]$. The reaction profile consisted of an initial denaturation step at $95^{\circ} \mathrm{C}$ for $3 \mathrm{~min}, 40$ cycles of $30 \mathrm{~s}$ at $95^{\circ} \mathrm{C}, 30 \mathrm{~s}$ at $42^{\circ} \mathrm{C}$ and $30 \mathrm{~s}$ at $72{ }^{\circ} \mathrm{C}$, to then be held at $15^{\circ} \mathrm{C}$.

\section{Polyvalent PCR detection of Begomoviruses}

Polyvalent detection of begomoviruses was performed employing the primers developed by the CIRAD UMR-PVBMT (Table 1) and the GoTaq Flexi PCR Promega Kit (Ref M8306), using samples of $2 \mu \mathrm{L}$ of DNA extracted from leaves as a template, according to the following amplification conditions: total DNA denaturation for $3 \mathrm{~min}$ at $95^{\circ} \mathrm{C}, 35$ cycles of denaturation at $95^{\circ} \mathrm{C}$ for $45 \mathrm{~s}$, annealing of primers at $60^{\circ} \mathrm{C}$ for $45 \mathrm{~s}$ and extension by the Taq polymerase at $72^{\circ} \mathrm{C}$ for $45 \mathrm{~s}$, with a final extension step of $7 \mathrm{~min}$ at $72^{\circ} \mathrm{C}$.

Visualization of amplicons by electrophoresis on agarose gels.

In all experiments, the amplicons were visualized through electrophoresis on $1.5 \%$ agarose gels with ethidium bromide staining, according to the protocol of SequiGen ${ }^{\circ}$ GT Nucleic Acid Electrophoresis Cell Instruction Manual from BIO-RAD, taking as reference the positive control TNAs from infected dried sweet potato leaves provided by CIRAD, UMR BGPI Montpellier for begomoviruses, TNAs from infected dried Nicotiana benthamiana leaves provided by CIRAD Reunion for potyviruses and TNAs from infected dried sweet potato leaves provided by CIRAD, UMR BGPI Montpellier for carlaviruses, and using nuclease-free water as a negative control. Comparisons with the AmpliSize Molecular Ruler 50-2,000 bp from BIO-RAD allowed determining the size of the amplicons. 


\section{Sequencing of the amplicon obtained from the Carlavirus infecting ISOP1011}

The sequence of the amplicon obtained from accession ISOP1011 was determined on an automated DNA sequencer (ABI prismtm 377 DNA sequencer) at the INRAE Bordeaux Laboratory or the CIRAD UMR-PVBMT. Clones from independent PCR reactions were sequenced from both ends to minimize any error caused by Taq polymerase.

\section{Bioinformatic analysis of the sequence}

The DNA sequence editor WebDSV (http://www.molbiotools.com/WebDSV/) allowed the graphic representation of the virus sequence obtained, which was designated throughout this work as ISOP1011Carlavirus (ISOP1011-CV).

Nucleotide sequence analysis was carried out employing the Open Reading Frame Finder (ORF Finder - https://www.ncbi.nlm.nih.gov/orffinder/) from the National Center for Biotechnology Information (NCBI). InterProScan (http://www.ebi.ac.uk/interpro/search/sequence/) and the Conserved Domain Search Service (CD Search - https://www.ncbi.nlm.nih.gov/Structure/cdd/wrpsb.cgi) were used in the identification of conserved domains.

The different modalities of the BLAST program (https://blast.ncbi.nlm.nih.gov/Blast.cgi), were applied in the comparison of the ISOP1011-CV sequence with those deposited in databases.

Multiple sequence alignment of ISOP1011-CV predicted amino acid sequence and some RdRp similar sequences, was possible by implementing T-Coffee Server tools from Notredame's Lab (http://tcoffee.crg.cat/apps/tcoffee/index.html). Editing of the multiple sequence alignment was performed with the Jalview program, version 2.11.1.0.

The phylogenetic analysis of ISOP1011-CV concerning all the species of Carlavirus genus reported in the group of orthologs 4at12163 of OrthoDB $v 10.1$ (https://www.orthodb.org/?level=12163\&species=12163\&query=4at12163) and NCBI Taxonomy database (https://www.ncbi.nlm.nih.gov/Taxonomy/Browser/wwwtax.cgi?id=12163), was performed on the Phylogeny.fr platform (http://www.phylogeny.fr/index.cgi) according to the following steps: 1.- alignment of the sequences with ClustalW (v2.1); 2.- removal of ambiguous regions (i.e. containing gaps and/or poorly aligned) using Gblocks (v0.91b), according to the following parameters: minimum length of a block after gap cleaning: 10, no gap positions were allowed in the final alignment, all segments with contiguous non-conserved positions bigger than 4 were rejected and a minimum number of sequences for a flank position: $85 \%$; 3 .phylogenetic tree reconstruction using the maximum likelihood method implemented in the PhyML program (v3.1/3.0 aLRT). The default substitution model was selected assuming an estimated proportion of invariant sites (of 0.000) and 4 gamma-distributed rate categories to account for rate heterogeneity across sites. The gamma shape parameter was estimated directly from the data (gamma $=0.486)$. Reliability for the internal branches was assessed using the bootstrapping method (100 bootstrap replicates). Graphical representation of the phylogenetic tree was performed with iTOL (https://itol.embl.de/). The graphic shown in Figure 1A was created with the program Prism 3.0.

\section{Results}

Traditional cultivars of sweet potato from the ISOPlexis Genebank, detected in the polyvalent PCR assays as infected by Begomovirus, Potyvirus, and/or Carlavirus, are shown in Table 2. ISOP1005 and ISOP1027 were the only ones that were not infected by any of these viruses. The screening found that the proportion of cultivars infected by begomoviruses was $81.25 \%$, by potyviruses was $25 \%$, and by carlaviruses $6.25 \%$ (Figure 1A). 

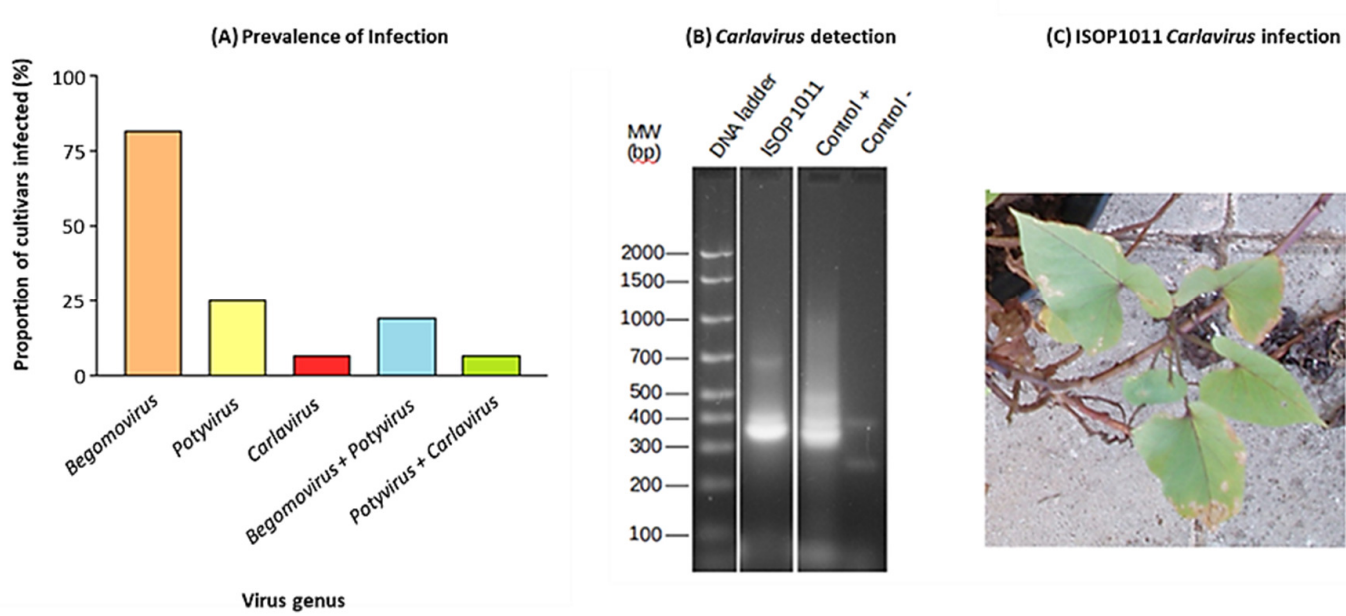

Figure 1. (A) Prevalence of begomoviruses, potyviruses, and a carlavirus infection in samples of sweet potato (Ipomoea batatas). (B) Agarose gel electrophoresis of the RT-PCR product obtained from the Carlavirus genomic RNA infecting the ISOP1011 germplasm cultivar. (C) Phenotypic characteristics of the viral infection of ISOP 1011 accession coinfected by a Carlavirus and Potyvirus

The accessions ISOP1006, ISOP1010 and ISOP1047 were coinfected with viruses of Begomovirus and Potyvirus genera, representing a percentage of $18.75 \%$ of the total analysed, while the accession ISOP 1011 was the only coinfected with Potyvirus and Carlavirus (6.25\%). This was the only accession collected in the Madeira Island from the locality of Gaula. On the other hand, there was no correlation between the kind of infection and the localities on the island where the cultivars had been collected.

Table 2. Accessions of traditional sweet potato cultivars infected by virus genus

\begin{tabular}{|c|c|c|c|}
\hline \multirow{2}{*}{ Cultivar } & \multicolumn{3}{|c|}{ Virus genus } \\
\hline & Begomovirus & Potyvirus & Carlavirus \\
\hline ISOP1005 & - & - & - \\
\hline ISOP1006 & $+(3)$ & $+(1)$ & - \\
\hline ISOP1009 & $+(4)$ & - & - \\
\hline ISOP1010 & $+(4)$ & $+(2)$ & - \\
\hline ISOP1011 & - & $+(3)$ & $+(2)$ \\
\hline ISOP1012 & $+(4)$ & - & - \\
\hline ISOP1013 & $+(4)$ & - & - \\
\hline ISOP1016 & $+(4)$ & - & - \\
\hline ISOP1020 & $+(4)$ & - & - \\
\hline ISOP1021 & $+(3)$ & - & - \\
\hline ISOP1027 & - & - & - \\
\hline ISOP1028 & $+(2)$ & - & - \\
\hline ISOP1036 & $+(4)$ & - & - \\
\hline ISOP 1038 & $+(4)$ & - & - \\
\hline ISOP1047 & $+(4)$ & $+(3)$ & - \\
\hline ISOP1064 & $+(4)$ & - & - \\
\hline
\end{tabular}

The positive sign (+) indicates that infection was detected in at least one of the 4 replicates for each cultivar, while the negative sign (-) indicates that none of the replicates examined registered signs of infection through polyvalent PCR screening. The number of infected samples of the 4 replicates tested per variety is shown in parentheses. Accessions coinfected by virus of several genera are underlined. 
Because it is the first time a virus of the genus Carlavirus has been detected in Madeiran sweet potatoes, affecting a single cultivar of all the varieties evaluated, we decided to sequence the amplicon corresponding to the RdRp encoded in the ISOP1011-CV genomic RNA. The amplicon obtained had the expected size of approximately $360 \mathrm{bp}$, as seen in Figure 1B. The characteristics of the visual damages caused by the viral infection on the leaves can be seen in Figure 1C. However, since ISOP1011 was coinfected by potyviruses and a carlavirus, it was not possible to attribute these lesions specifically to any of these two viral groups. The main symptoms of infection were mosaic and chlorotic leaf lesions, which could be observed as isolated or overlapping yellow spots, with reduced areas of brown coloration and a predominant location on the edge of the leaves, causing their curling or deformation.

As it was expected, the nucleotide sequence analysis of the ISOP1011-CV amplicon revealed the existence of an ORF starting at nucleotide 62 from the 5 'end of the DNA strand that corresponds to the virus genomic RNA with a positive (+) sense, that encodes 93 amino acids of an RdRp related to the Tymovirus protein family (IPR001788), as reported by a search for domains and motifs in the InterPro database (Figure 2). The ISOP1011-CV was the only isolate identified down to species level, while the screening of the remaining viruses was only possible up to genera.

This finding was confirmed by a consultation of the NCBI Conserved Domain Database, in which it was determined that the sequence of the identified virus contains the RdRp_2 Superfamily domain cl03049, whose only member is the family pfam00978. Since this domain is between nucleotides 2 and 343 of our sequence (Figure 2), we could infer it encompasses another part of the sequence that codes for this polyprotein.

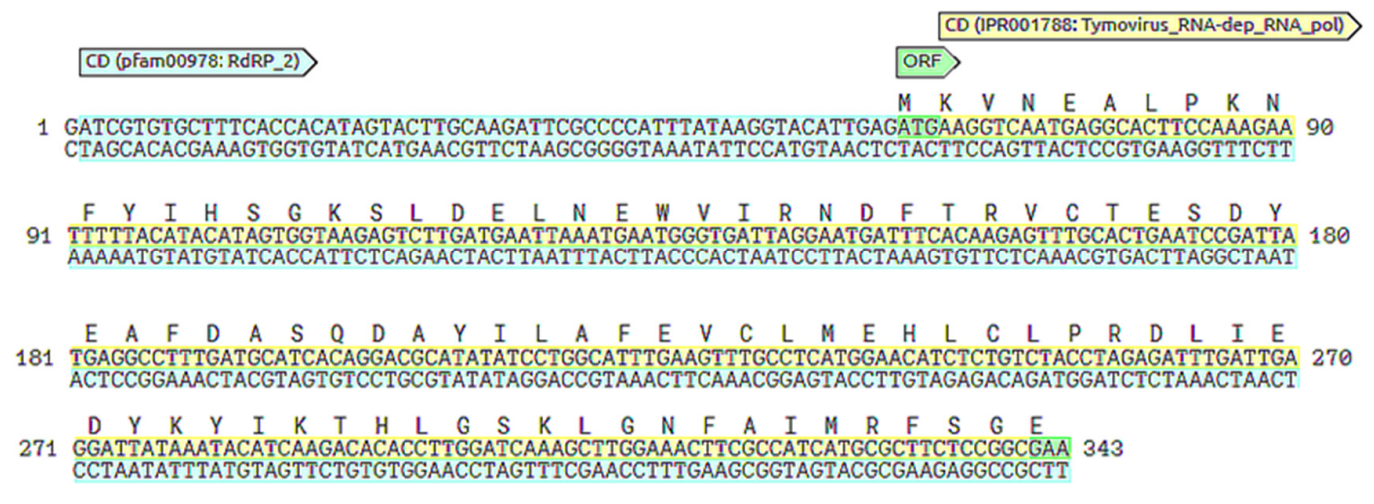

Figure 2. Nucleotide sequence of the RT-PCR product from the isolation of Carlavirus RNA infecting the ISOP1011 accession of sweet potato

The beginning of the open reading frame (ORF) and conserved domains (CD) IPR001788 and pfam00978 of RdRps are shown with arrows, which were identified using the ORF Finder, InterProScan, and CD Search tools and are highlighted in green, yellow and blue colours, respectively. The possible amino acid sequence encoded by the ORF, predicted from the standard genetic code, is shown in capital letters located above the sequence base pairs.

The search for sequence similarity between ISOP1011-CV and the sequences deposited in the GenBank

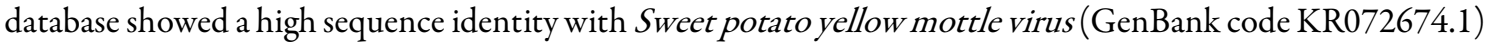
and $S_{w e e t}$ potato chlorotic fleck virus isolates HG176 (Genebank code KP715159.1). The expected (E) statistical significance score values close to zero, the length of the alignments, and the fact these virus species were isolated from sweet potato, also indicate the evolutionary relationship between them is significant. Although the sequence identity is high, there is a 9-11\% discrepancy between them and the ISOP1011-CV, respectively.

Comparison of the nucleotide sequence of ISOP1011-CV translated into a protein with that of the wellcharacterized proteins contained in the UniProtKB/Swiss-Prot database, through the BLASTx program, allowed us to find considerable sequence similarity with RNA replication proteins (RdRps) of various species 
of plant viruses. Thus, it is possible to ensure that the sequence obtained from ISOP1011-CV corresponds to part of the gene that codes for the enzyme involved in the replication of this virus.

Multiple sequence alignment of ISOP1011-CV predicted amino acid sequence and some of the sequences detected by BLASTx, established that they have the catalytic domain of this enzyme in common. This domain is quite conserved and is translated as part of RNA replication polyprotein, that encompasses the following domains: Alphavirus-like MT, Fe2OG dioxygenase, OTU, Peptidase C23, (+) RNA virus helicase ATP-binding, (+) RNA virus helicase C-terminal, and the catalytic domain, as observed when examining the proteins Q65652, P17965, Q64962, Q91QZ3, P54891, Q6PLS1, P36309, Q67704, Q9DRA1, and Q07630, described in Uni-ProtKB/Swiss-Prot (Figure 3). The multiple sequence alignment also shows the catalytic domains of the RdRps of all these viruses maintain Motifs A and B highly conserved (Figure 3). However, there are amino acid substitutions in these ISOP1011-CV highly conserved domains.

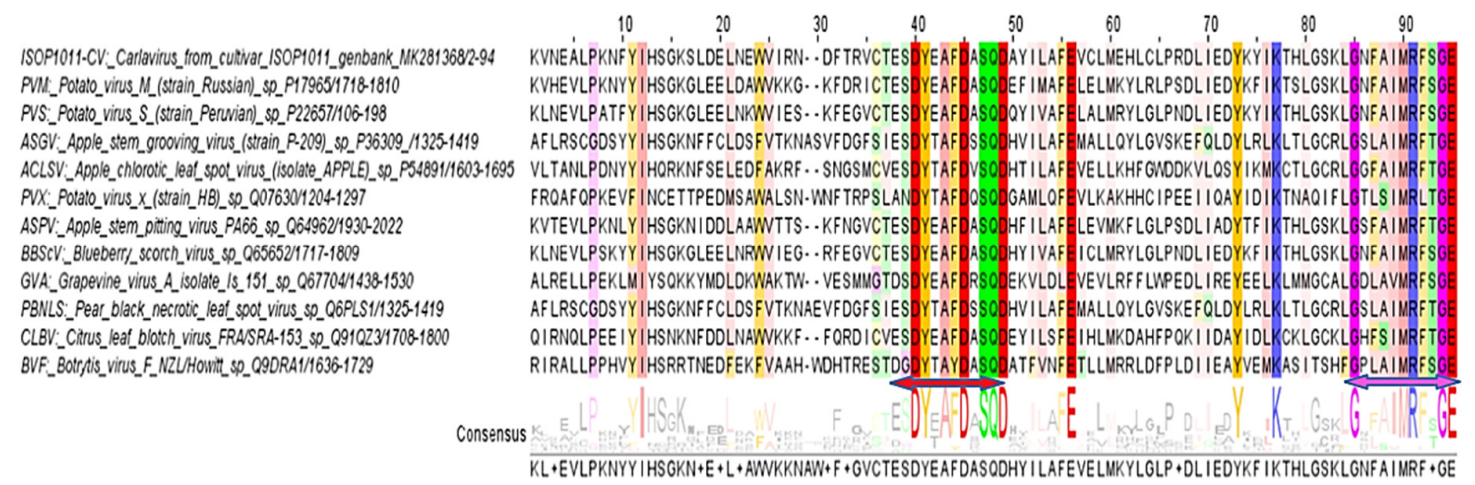

Figure 3. Multiple sequence alignment of ISOP1011-CV predicted amino acid sequence and the RdRp sequences of several viruses

The name of each virus is indicated, followed by its accession code in the Genbank or UniProtKB/Swiss-Prot (sp) databases and the coordinates of the aligned regions. The residues are coloured according to their physicochemical properties as follows: aliphatic/hydrophobic (salmon), aromatic (mustard), positive (blue), negative (red), hydrophilic (green), conformationally special (pink), and cysteine (yellow). The double-headed arrow segment in red indicates Motif A, while the pink highlights Motif B.

The phylogenetic analysis carried out using the maximum probability method shows that ISOP1011$\mathrm{CV}$ is a new viral divergent strain of the $S_{\text {weet }}$ potato chlorotic fleck virus (SPCFV) (Figure 4). The bootstrap values indicate that this divergence is significant. The comparison of the ISOP1011-CV nucleotide sequence translated into protein, with the sequences deposited in the NCBI non-redundant protein sequences database (using BLASTx), confirmed it is within the SPCFV species (data not shown), together with the SPYMV (which has not yet been recognized as an official ICTV different species). Nevertheless, it has a significantly weaker evolutionary relationship with SPYMV, according to the bootstrap results. The nucleotide sequence similarity with SPCFV and SPYMV found in the BLASTn search supports its classification within the same virus species. Additionally, ISOP1011-CV is part of a monophyletic deeply rooted clade made up of MYAV (Melon yellowing-associated virus), SPYMV, and SPCFV (Figure 4). Notoriously, two other members of this clade, apart from ISOP1011-CV, are viruses that have been isolated from sweet potato.

On the other hand, according to the sequence of RdRps of Garlic latent virus E29-6(GLV CAA47613) and Sugarcane striate mosaic virus (ScSMV AAD10481), these viruses appear to be evolutionarily more distant from the rest of the members of the Carlavirus genus, than the Cherry virus A (CVA BCA25839) of the genus Capillovirus used as a reference outgroup.

It was not possible to establish the phylogenetic relationship between ISOP1011-CV and the viruses: LiLV (sp Q9QBX0), CLV (ACL81510), HVS (ACL81508), HeMV (YP_009664740), SjoLV (NC_043084), BCVA (AWX68111), CCV1 (MK415316), FLV (ADZ17164), SeLV (ACM41724) and TsLSV (AAY43099), probably due to lack of similarity between their available partial sequences. 


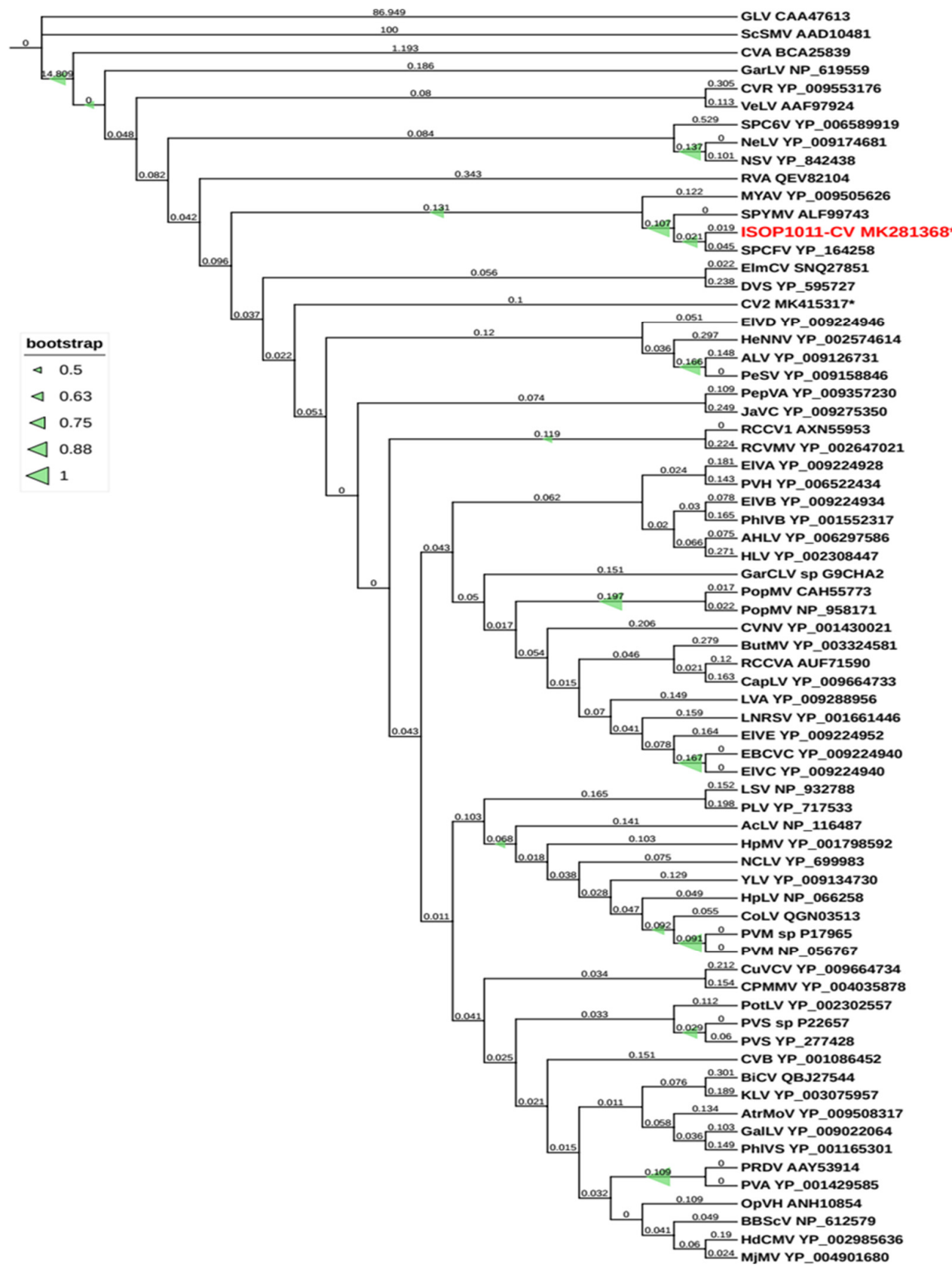

Figure 4. Phylogenetic relationship of ISOP1011-CV with viruses of the Carlavirus genus

The phylogenetic tree was constructed using the maximum likelihood method. Values derived from bootstrap analysis with 100 replicates are shown as green triangles. On the branches are the values corresponding to the number of amino acid substitutions per site. CVA (BCA25839) was included as an outgroup for comparative purposes. The names of the viruses are represented by their initials, followed by their accession code in the databases of UniProtKB/Swiss-Prot (sp), Proteins, or Nucleotides (Genbank) of the NCBI. The ISOP1011-CV position is highlighted in red and * denotes those nucleotide sequences translated into a protein with the standard genetic code. 


\section{Discussion}

Begomovirus, Potyvirus, and Carlavirus are included in the group of over 20 genera of viruses that can infect sweet potatoes (Valverde et al., 2007). Screening for Begomovirus, Potyvirus, and Carlavirus infections, in 64 samples from 16 traditional sweet potato cultivars, showed a higher prevalence of Begomovirus infections, 48 samples, compared to the other two viruses Potyvirus (9 samples) and Carlavirus (2 samples) (Table 2; Figure 1A). These results were expected since Ipomoea batatas and other Ipomoea species are frequently infected by monopartite Begomoviruses (Trenado et al., 2011). This higher prevalence of Begomovirus infections could be explained by the fact that it is transmitted by whiteflies Bemisia tabacci(Gennadius, 1889), one of the most detrimental pests in agriculture, present in Madeira (Rosario et al., 2014). In this study the accessions ISOP1006, ISOP1010 and ISOP1047 were coinfected with Begomovirus + Potyvirus, while the accession ISOP1011 was the only accession coinfected by Potyvirus and Carlavirus, exposing the sweet potato vulnerability to these viral infections. These coinfections could have repercussions in the new, emerging viruses, through the processes of recombination and reassortment of the viral genomes (Weng et al., 2007). The high prevalence of infection by viruses of different genera poses a challenge for the cultivar's conservation in the germplasm collections and the international exchange of vegetative material. In this case, the lack of infections in accessions ISOP1005 and ISOP1027 requires further studies to determine the causes, such as possible resistance of these cultivars. The only accession (ISOP1011) infected with a Carlavirus has been collected in Gaula (Table 2) and has a different origin of those infected by begomoviruses and potyviruses, which could indicate that Carlavirus infection, as well as potyviruses, occurred in a confined area, whereas infection by begomoviruses is widely spread along sweet potato cultivation areas in the Madeira island.

The sequence analysis of the DNA fragment corresponding to the gene for the RdRp encoded in the genomic RNA of the Carlavirus isolated from leaves of ISOP1011 showed the presence of an ORF encoding 93 amino acids, related to the RdRps proteins (IPR001788) from the Tymovirus family. This finding was ratified by the presence of RdRp_2 Superfamily domain cl03049, whose only member is the family pfam00978. This last domain covers almost the entire 343 bp sequence obtained from this virus polyprotein.

Comparison of the ISOP1011-CV sequence (Da Silva et al., 2020), with proteins contained in the UniProtKB/Swiss-Prot database, found considerable sequence similarity with RdRps of plant viruses from the Order Tymovirales, mainly with four species of the Carlavirus genus, family Betaflexiviridae, Quinvirinae Subfamily, indicating the existence of a closed evolutionary relationship.

Multiple sequence alignment of ISOP1011-CV predicted amino acid sequence and some of the RdRp sequences identified in UniProtKB/Swiss-Prot, established that they have in common the catalytic domain of this enzyme (Figure 3). These are the only domains of this key enzyme for this RNA virus's replication protein, highly conserved in ISOP1011-CV, especially the Motifs A and B. The RdRps are the most conserved of all proteins encoded by diverse viruses and possess a "right hand-like" three-dimensional structure with an active site consisting of Motifs $A \rightarrow B \rightarrow C$ (Sabanadzovic et al., 2009). The partial sequence of ISOP1011-CV only allowed to identify Motifs A and B; two of the three motifs found in the "palm" sub-domain, which is the most conserved of the three sub-domains identified as "finger", "palm" and "thumb" of all viral RdRps (Koonin, 1991). Motifs A and C contain conserved Aspartic (D) residues that are spatially juxtaposed and involved in a two-metal $\left(\mathrm{Mg}^{2+}\right.$ and/or $\left.\mathrm{Mn}^{2+}\right)$ catalysis mechanism ( $\mathrm{Ng}$ et al., 2008). This pattern of Aspartic residues is also conserved in the ISOP1011-CV (Figure 3). Motive B determines whether RNA or DNA will be synthesized by selecting the specific nucleotide type that will be incorporated into the molecule (Hansen et al., 1997). However, amino acid substitutions were observed in this highly conserved domain, supporting the idea that ISOP1011-CV could be a new divergent strain of the SPCFV species of the Carlavirus genus.

The phylogenetic analysis encompassing all the RdRp orthologs of 79 Carlavirus species reported in the NCBI Taxonomy database and/or OrthoDB v10.1, established a significant phylogenetic relationship between ISOP1011-CV and the species Melon yellowing-associated virus (MYAV), Sweet potato yellow mottle virus (SPYMV), and Sweet potato chlorotic fleck virus (SPCFV), placing them within the same monophyletic deeply 
rooted clade (Figure 4). SPYMV and SPCFV viruses are pathogens of sweet potato and produce pathogenic effects similar to those observed in ISOP1011 (Figure 1C). Furthermore, both viruses were associated with ISOP1011-CV as the result of the BLASTn search for similar sequences in the genebank non-redundant sequence database. All these data obtained employing different bioinformatic tools, support the phylogenetic relationship between the viruses grouped in this clade, suggesting that could have evolved from a common ancestor. Notwithstanding, according to the BLASTn megablast comparison matrix, specially created to find highly similar nucleotide sequences, there is a 9-11\% variation between ISOP1011-CV and its closest relatives SPYMV and SPCFV, respectively. Both, this divergence and the one established through the maximum probability phylogenetic analysis, support the identification of ISOP1011-CV as a new divergent isolate of Carlavirus belonging to the species SPCFV. Similar evidence can be obtained from the comparison of the ISOP1011-CV nucleotide sequence translated into protein, with the protein sequences deposited in the NCBI non-redundant protein sequences database (data not shown).

Since ISOP 1011-CV does not meet the demarcation criteria for isolates of different species in the family Betaflexiviridae of less than $72 \%$ nucleotide identity in the replicase genes, recommended by the International Committee on Taxonomy of Viruses (Adams et al., 2012), the authors consider it could be a new divergent isolate of SPCFV due to the differences found in the partial sequence of the region that codes for the highly conserved catalytic domain of this protein, similar to the divergence between SPCFV and SPYMV. Additionally, the RdRp sequence has already proven to be quite reliable in determining the phylogenetic relationship between different species of Betaflexiviridae (Silva et al., 2019).

The rapid mutational change that positive-strand RNA viruses can undergo outside the arrays of conserved sequence motifs of enzymes mediating the replication and expression of virus genomes (Koonin and Dolja, 1993), could explain the ISOP1011-CV significant divergence from SPCFV species isolates.

\section{Conclusions}

The information derived from this screening is essential to avoid the exchange and distribution of infected germplasm samples, the preservation of the collection of traditional sweet potato cultivars kept in the ISOPlexis Germplasm Bank, the selection of material free of viral infections, also, to point out the locations where biosafety measures are required to control the wider spread of these viral pathologies, in which polyvalent molecular diagnostic tools of viruses that negatively affect the productivity and quality of these cultures play an indispensable role.

\section{Authors' Contributions}

Conceptualization: ES, CA, and MC; Investigation: ES, CA; Writing - original draft preparation: ES, CA; Writing - review and editing: CR, CA, and MC; Supervision: MC; Funding acquisition: ES, MC. All authors read and approved the final manuscript.

\section{Acknowledgements}

The authors acknowledge the Regional Secretariat for the Environment and Natural Resources. This work is supported by National Funds by FCT - Portuguese Foundation for Science and Technology, under the project UIDB/04033/2020, by the project Safe PGR through program ANR NET-BIOME 2010-2011, as well as the Institute for Regional Development (IDR) for funding CASBio project (M1420-01-0145-FEDER000011), and by the Agência Regional para o Desenvolvimento da Investigação, Tecnologia e Inovação, 
Portugal 2020 and the European Union through the European Social Fund [grant number M1420-09-5369FSE000002, ARDITI].

\section{Conflict of Interests}

The authors declare that there are no conflicts of interest related to this article.

\section{References}

Adams MJ, Candresse T, Hammond J, Kreuze JF, Martelli GP, Namba S, ...Yoshikawa N (2012). Family Betaflexiviridae. In: King AMQ, Adams MJ, Carstens EB, Lefkowitz EJ (Eds). Virus Taxonomy. Ninth Report on the International Committee on Taxonomy of Viruses. Elsevier Academic Press Cambridge pp 920-941. https://doi.org/10.1016/B978-0-12-384684-6.00078-1

Barkessa MKE (2018). A review on sweet potato (Ipomea batatas) viruses and associated diseases. International Journal of Research in Agriculture and Forestry 5(9):1-10.

Clark CA, Davis JA, Abad JA, Cuellar WJ, Fuentes S, Kreuze JF, ...Valkonen JP (2012). Sweet potato viruses: 15 years of progress on understanding and managing complex diseases. Plant Diseases 96(2):168-185. http://dx.doi.org/10.1094/PDIS-07-11-0550

Cuellar WJ, Galvez M, Fuentes S, Tugume J, Kreuze J (2015). Synergistic interactions of Begomoviruses with sweet potato chlorotic stunt virus (genus Crinivirus) in sweet potato (Ipomoea batatas L.): sweet potato Begomovirus synergism with SPCSV. Molecular Plant Pathology 16(5):459-471. https://doi.org/10.1111/mpp.12200

Da Silva EM, dos Santos TMM, Pavis C, Pinheiro de Carvalho, MAA (2020). Sweet potato chlorotic fleck virus RNA dependent RNA polymerase gene, partial cds. GenBank: MK281368 NCBI. https://www.ncbi.nlm.nih.gov/nuccore/MK281368

Desbiez C, Moury B, Lecoq H (2011). The hallmarks of "green" viruses: Do plant viruses evolve differently from the others? Infection, Genetics and Evolution 11(5):812-824. https://doi.org/10.1016/j.meegid.2011.02.020

Elena SF, Agudelo-Romero P, Carrasco P, Codoner FM, Martin S, Torres-Barceló C, Sanjuán R (2008). Experimental evolution of plant RNA viruses. Heredity 100(5): 478-483. https://doi.org/10.1038/sj.hdy.6801088

FAOSTAT (2012). Crop production data 2012. Retrieved 2020 July 01 from http://faostat.fao.org

Foissac X, Svanella-Dumas L, Gentit P, Dulucq MJ, Marais A, Candresse T (2005). Polyvalent degenerate oligonucleotides reverse transcription-polymerase chain reaction: a polyvalent detection and characterization tool for trichoviruses, capilloviruses, and foveaviruses. Phytopathology 95(6):617-625. https://doi.org/10.1094/PHYTO-95-0617

Gennadius P (1889). Disease of the tobacco plantations in the Trikonia. The aleurodid of tobacco. Ellenike Georgia 5:13.

Hansen JL, Long AM, Schultz SC (1997). Structure of the RNA dependent RNA polymerase of poliovirus. Structure 5(8):1109-1122. https://doi.org/10.1016/S0969-2126(97)00261-X

International Potato Center (2018). Sweet potato facts and figures. Retrieved 2020 March 27 from https://cipotato.org/crops/sweetpotato/sweetpotato-facts-and-figures/2018

Johansen E, Edwards MC, Hampton RO (1994). Seed transmission of viruses: current perspectives. Annual review of phytopathology 32(1):363-386.

Koonin EV (1991). The phylogeny of RNA-dependent RNA polymerases of positive-strand RNA viruses. Journal of General Virology 72(9):2197-2206.

Koonin EV, Dolja VV (1993). Evolution and taxonomy of positive-strand RNA viruses: implications of comparative analysis of amino acid sequences. Critical Reviews in Biochemistry and Molecular Biology 28(5):375-430.

Lozano G, Trenado HP, Valverde RA, Navas-Castillo J (2009). Novel Begomovirus species of recombinant nature in sweet potato (Ipomoea batatas) and Ipomoea indica: taxonomic and phylogenetic implications. Journal of General Virology 90(10):2550-2562. https://doi.org/10.1099/vir.0.012542-0

Mohanraj R, Sivasankar S (2014). Sweet potato (Ipomoea batatas [L.] Lam) a valuable medicinal food: a review. Journal of Medicinal Food 17(7):733-741. http://doi.org/10.1089/jmf.2013.2818 
Ng KS, Arnold JJ, Cameron CE (2008). Structure-function relationships among RNA-dependent RNA polymerases. In: Paddison PJ, Vogt PK (Eds). RNA Interference. Current Topics in Microbiology and Immunology. vol 320. Springer, Berlin, Heidelberg pp 137-156. https://doi.org/10.1007/978-3-540-75157-1_7

Rice W (1983). Sexual reproduction: an adaptation reducing parent-offspring contagion. Evolution 37(6):1317-71320. https://doi.org/10.2307/2408851

Ooi K, Yahara T (1999). Genetic variation of geminiviruses: comparison between sexual and asexual host populations. Molecular Ecology 8(1):89-97.

Roossinck MJ, Martin DP, Roumagnac P (2015). Plant virus metagenomics: advances in virus discovery. Phytopathology 105(6):716-727. https://doi.org/10.1094/PHYTO-12-14-0356-RVW

Rosario K, Capobianco H, Ng TFF, Breitbart M, Polston JE (2014). RNA viral metagenome of whiteflies leads to the discovery and characterization of a whitefly-transmitted Carlavirus in North America. PLoS One 9(1):e86748. https://doi.org/10.1371/journal.pone.0086748

Sabanadzovic S, Aboughanem N, Gorbalenya A (2009). Permutation of the active site of putative RNA-dependent RNA polymerase in a newly identified species of plant alpha-like virus. Virology 394(1):1-7. https://doi.org/10.1016/j.virol.2009.08.006

Silva G, Bömer M, Rathnayake AI, Sewe SO, Visendi P (2019). Molecular characterization of a new virus species identified in yam (Dioscorea spp.) by high-throughput sequencing. Plants 8(6):167. https://doi.org/10.3390/plants8060167

Stewart AD, Logsdon JM, Kelley SE (2005). An empirical study of the evolution of virulence under both horizontal and vertical transmission. Evolution 59(4):730-739.

Trenado HP, Orílio AF, Márquez-Martín B, Moriones E, Navas-Castillo J (2011). Sweepoviruses cause Disease in sweet potato and related Ipomoea spp.: fulfilling koch's postulates for a divergent group in the genus Begomovirus. PLoS One 6(11):e27329. https://doi.org/10.1371/journal.pone.0027329

Umer M, Liu J, You H (2019). Genomic, morphological and biological traits of the viruses infecting major fruit trees. Viruses 11(6):515. https://doi.org/10.3390/v11060515

Valverde RA, Clark CA, Valkonen JP (2007). Viruses and virus disease complexes of sweetpotato. Plant Viruses 1(1):116126.

Weng Z, Barthelson R, Gowda S, Hilf ME (2007). Persistent infection and promiscuous recombination of multiple genotypes of an RNA virus within a single host generate extensive diversity. PLoS One 2(9):e917. https://doi.org/10.1371/journal.pone.0000917

Zheng L, Rodoni BC, Gibbs MJ, Gibbs A (2010). A novel pair of universal primers for the detection of Potyviruses. Plant Pathology 59(2):211-220. https://doi.org/10.1111/j.1365-3059.2009.02201.x

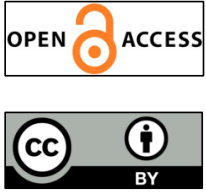

The journal offers free, immediate, and unrestricted access to peer-reviewed research and scholarly work. Users are allowed to read, download, copy, distribute, print, search, or link to the full texts of the articles, or use them for any other lawful purpose, without asking prior permission from the publisher or the author.

License - Articles published in Notulae Botanicae Horti Agrobotanici Cluj-Napoca are Open-Access, distributed under the terms and conditions of the Creative Commons Attribution (CC BY 4.0) License. (c) Articles by the authors; UASVM, Cluj-Napoca, Romania. The journal allows the author(s) to hold the copyright/to retain publishing rights without restriction. 